\title{
Epigenetic Mechanisms may Underlie the Aetiology of Sex Differences in Mental Health Risk and Resilience
}

\author{
S. L. Kigar ${ }^{\star}$ and A. P. Auger ${ }^{\dagger}$ \\ "Molecular and Cellular Pharmacology Training Program, University of Wisconsin-Madison, \\ Madison, WI, USA \\ tDepartment of Psychology, Neuroscience Training Program, University of Wisconsin-Madison, \\ Madison, WI, USA
}

\begin{abstract}
In this review, we propose that experiential and hormonal influences on biological sex during development may produce differences in the epigenome, and that these differences play an important role in gating risk or resilience to a number of neurological and psychiatric disorders. One intriguing hypothesis is that the framework belying sex differences in the brain creates differences in methylation and demethylation patterns, and these in turn confer risk and resilience to mental health disorders. Here, we discuss these concepts with regard to social behaviour in rodent models and briefly discuss their possible relevance to human disease.
\end{abstract}

\section{Keywords}

epigenetics; juvenile; play behaviour; sexual differentiation; methylation; steroid hormones; amygdala

Biological sex can be considered a significant risk factor for numerous mental health disorders because there are differences in the diagnostic rates between genders of such apparently disparate conditions as autism spectrum disorders (1), early-onset schizophrenia (2), major depressive disorders (3), stress/anxiety-related disorders (4) and anorexia nervosa (5) (Table 1). Given such a discrepancy, the obvious questions to arise are: what belies the aetiology of sex differences in the brain, and how does this manifest as differential susceptibility to pathology? Although alterations in the genetic code are implicated in many of these disorders, epigenetic modifications to the genome may also be a contributing factor. This review will attempt to address what is known about the organisation of sex differences in the brain during development and to discuss important epigenetic factors associated with psychiatric disorders. It should be noted that we define epigenetics as a dynamic or maintained change to chromatin (i.e. DNA-histone complexes), which alters or has the potential to alter gene transcription without necessarily modifying the underlying DNA

(C) 2013 British Society for Neuroendocrinology

Correspondence to: Anthony P. Auger, Department of Psychology, Neuroscience Training Program, University of WisconsinMadison, Madison, WI 53706, USA (apauger@wisc.edu).. 
code. This definition differs slightly from that of Bird (9) with respect to its emphasis on the transient nature of these epigenetic marks.

Although neuronal sex differences are present at birth as a result of both genetic and hormonal organisation (10), chemical and morphological changes continue to occur postnatally and into adulthood. We discuss briefly how these variances emerge and their translation to sex differences in the epigenome. A model is presented in which sex-specific epigenetic programming of the amygdala is critical for typical juvenile social interactions. Additionally, we discuss data associating variations in epigenetic factors with mental health risk, making them a plausible culprit in conferring risk or resilience to mental health disorders.

\section{Hormonal activation of neural circuits in the developing brain}

The developing brain is exquisitely sensitive to the effects of circulating steroid hormones during so-called sensitive periods of perinatal development. Although the timing of hormone sensitivity varies by species, the sex-determining mechanism is conserved between placental and marsupial mammals, dating it at some 148 million years (11). Briefly, SRY on the Y chromosome is a transcription factor that serves to differentiate the bipotential gonad into testes. Leydig cells within the testes begin producing testosterone in utero and in substantially greater amounts than the female ovaries (12). Testosterone can then enter the brain, where it is aromatised or reduced into oestradiol or dihydrotestosterone, respectively. These metabolites subsequently bind to oestrogen receptors (ERs) or androgen receptors (ARs) and result in masculinisation and defeminisation of the brain, especially those systems pertinent to reproduction $(13,14)$.

Generally speaking, hormone binding to its cognate nuclear receptor results in a conformational change that releases the receptor from heat shock proteins. Nuclear receptors can then dimerise and translocate to the nucleus where they bind to response elements in gene promoter regions and recruit coregulatory proteins. Coactivator proteins, such as cAMP-response element binding protein-binding protein (CBP) and steroid receptor coactivator 1 (SRC1), contain intrinsic histone acetylation activity that relaxes the tight coiling of negatively-charged DNA to positively-charged histones, allowing for more efficient access of the transcriptional machinery (15) (Fig. 1). Interestingly, both CBP and SRC-1 are expressed more highly in males during the early neonatal period in rat brain $(11,12)$, whereas co-repressors are expressed more highly in females (see below), likely resulting in sex-specific epigenomic variation.

Perinatal hormonal surges occur mostly during discrete windows of time during development, although they can have relatively stable organisational effects on an organism's behaviour and physiology, thus rendering sexual differentiation a useful model by which we can begin to study lasting epigenetic processes in the brain. Although hormones and experience significantly alter sexually dimorphic brain regions (e.g. hypothalamic regions related to stress, preoptic area (POA) control of reproduction), sex differences in the epigenetic reprogramming of gene function are also known to occur within the amygdala, a region critical for socio-emotional processes (16). 


\section{Critical involvement of the amygdala in social behaviour}

The amygdala (so named from the Greek because of its almond-like shape) is a small, complex structure in the medial temporal lobe known to be of central importance in emotion processing, conditioned fear learning and modulation of social behaviours $(17,18)$. A primitive amygdalar structure can be found in amphibians, dating it to before the amphibian-amniote split, or some 315 million years (19). Lesion studies have provided ample evidence of an amygdalar role in social/emotional integration in both human and nonhuman primates; they furthermore implicate that the time of lesioning significantly impacts the severity of deficits, with childhood or congenital lesions having the most detrimental effects on later functioning $(17,20)$. Importantly, disruption of normal amygdala development has been noted in a plethora of neurodevelopmental disorders (e.g. autism, schizophrenia, anxiety disorders, childhood bipolar disorder) $(21,22)$. The timing of amygdala development in relationship to other sexually differentiated brain regions is less clear. In rodents, this system remains plastic in response to hormone manipulation into adulthood (23); in humans, the amygdala appears to develop approximately 5 months postfertilisation and remains relatively plastic until late adolescence, unlike other primate species $(17,18,21)$. It is well known that the amygdala is extremely steroid responsive, as high expression levels of ERs and ARs can be found in this structure early in development (24-31), making it a region of considerable interest in understanding the sexual differentiation of social behaviours and associated pathologies.

\section{Organisation of juvenile social play behaviour by steroid hormones}

One well-studied example of sexually dimorphic behaviour is juvenile social play. Juvenile play behaviour has emerged as an important developmental event that can both facilitate future social interactions and confer normal cognitive abilities later in life (24). Sex differences in frequency of initiation of so-called 'rough and tumble play' are observed in myriad species, including humans (32-34), nonhuman primates (25), dogs (35), cats (36) and rodents (37). Organisation of play behaviour occurs, in part, within the amygdala as a result of the presence of sex hormones, although the relative contributions of androgens and oestrogens are unclear and may be species-specific (24-30). Although there are many theories as to why animals play, abnormal play behaviour may be a good experimental model for social anhedonia, a common component of multiple neurodevelopmental disorders $(24,38-40)$.

\section{Studies in rodents}

In rodents, males are more likely to initiate play and engage in more bouts overall, as scored by tracking pouncing, boxing, pinning, biting and chasing (28). Implanting testosterone directly into the amygdalae of newborn female rat pups effectively masculinised play (30). Conversely, castrating males on the day of birth reduces bouts of play to female-typical levels $(27,28)$. Furthermore, analysis of male play behaviour in the testicular feminised mutation $(\mathrm{tfm})$ rat, wherein a point mutation to the steroid-binding domain of AR renders it unable to bind androgens, demonsrates reduced levels of play (26). However, male $t f m$ rats, although exhibiting less play behaviour than control males, tended to play more frequently 
than females and certain components of play remained at male-typical levels, indicating androgen receptors alone are insufficient to completely masculinise this behaviour $(26,41)$.

Our laboratory has shown that systemic treatment of neonatal female rats with a dose of oestradiol benzoate shown to result in male-like oestradiol levels in the hypothalamus (42) is sufficient to masculinise play behaviour, and this effect could be prevented by pretreatment with the selective oestrogen receptor modulator, tamoxifen (29). A unifying explanation for this apparent discrepancy in hormonal organisation may be that oestrogen masculinises some but not all components of play and otherwise 'primes' the brain for androgen exposure because oestradiol can selectively induce expression of AR mRNA (43). Additional evidence for the masculinisation of play behaviour by hormone exposure comes from intrauterine position studies. In litter-bearing mammals, females located between two male foetuses have an increased anogenital distance and exhibit more masculine play behaviour than females that are located between two other females (44).

\section{Studies in humans}

In humans, rough-and-tumble play is quantified by measuring playful physical assault, physical assault on an object and wrestling (33). These playful, nonharmful gestures are found across a wide spectrum of cultures (45) and can furthermore be observed in nonhuman primates (46), speaking to the evolutionary importance of such behaviours during development. Examples from human studies support sex differences in rough-and-tumble play behaviour and implicate a role for early steroid hormone exposure.

Congenital adrenal hyperplasia (CAH) - In individuals diagnosed with $\mathrm{CAH}$, normal cortisol production does not occur during the second month of gestation, ultimately leading to excess androgen accumulation in the body. Females with CAH frequently have ambiguous genitalia at birth, demonstrating the powerful effects in utero exposure to foetal testosterone can have on normal anatomical development (47). Interestingly, behavioural studies on these children have revealed that females with $\mathrm{CAH}$ engage in more aggressive play during childhood, and tend to prefer male playmates compared to sisters without this congenital abnormality, who themselves tend to prefer female playmates $(48,49)$.

Nonclinical population studies-Efforts have been made to correlate foetal testosterone exposure to gender role behaviour and/or rough and tumble play behaviour, with conflicting results depending on the method of analysis of foetal testosterone (50-52). The most recent data appear to suggest that higher levels of foetal testosterone exposure do correlate positively to increased rough and tumble play in human children (52).

\section{Effects of maternal care on play behaviour}

It has previously been shown in rats that there are natural variations in maternal care between dams, and that these variations drive epigenetic changes in factors responsible for stress reactivity, maternal behaviour and cognitive functioning (53-56). Pertinent here, male pups of dams exhibiting high levels of licking and grooming and arched back nursing (LGABN) play significantly less than pups from low LG-ABN dams (57). This effect was specific to males, as play fighting was not significantly different between females from high 
or low LG-ABN mothers. Our laboratory has focused on isolating the tactile stimulation component of maternal behaviour to eliminate the possibility that some factor in the nursing milieu is responsible for outcomes as a result of variations in maternal care in a paradigm that we term simulated maternal grooming. Our results recapitulate previous findings suggesting that male pups with higher levels of tactile stimulation play less overall and that this effect is sex-specific (58). It furthermore provides mechanistic data for reduced play behaviour, namely that serotonin receptor type IIa $\left(5-\mathrm{HT}_{2 \mathrm{~A}}\right)$ mRNA expression increases to female-typical levels. Because 5- $\mathrm{HT}_{2 \mathrm{~A}}$ expression seems to inversely correlate with aggression in both rats (59) and nonhuman primates $(60,61)$, it would appear that maternal care impinges on serotonergic pathways in males only and thereby reduces aggression. One enticing explanation for the male-specific effect of maternal care on rough-and-tumble play is that hormonal cues induce dams to engage in behaviour that will minimise overt sex differences. Specifically, rat dams tend to preferentially lick and groom their male offspring more than females (62). Injecting neonatal females with oestradiol, dihydrotestosterone or testosterone induces the mother to lick and groom them at male-typical levels, perhaps in part to temper the effects of hormones on play behaviour $(26,27,63)$.

Although maternal care reduces sex differences in juvenile social play, it appears to masculinise some gene expression patterns in females, and variations in maternal care can epigenetically reprogramme promoter regions of important transcription factors influencing behaviour within the developing hippocampus and POA of neonatal rats $(53,56)$. Our laboratory has shown that treatment of neonatal females with simulated maternal grooming increases amygdalar ERa promoter methylation, decreases ERa mRNA, and therefore phenocopies a male-typical ERa status (64). Although it is unclear whether these maternal cues are used in other species and to what extent, the maternal rearing environment is known to be a critical component of normal psychological development. For example, the importance of touch in human development has been well documented (65). One study quantifying the amount of touch contact French children versus American children received revealed that French infants, who receive more touch from their mothers than American children, are less aggressive (66).

Conversely, the effects of neglect or abuse have also been shown; for example, Harlow's controversial studies involving social isolation of rhesus monkeys clearly demonstrated the essential role of maternal care during infancy $(67,68)$; unsurprisingly, maternal deprivation results in lasting changes in the epigenome (69). Examination of post-mortem tissue from the brains of suicide victims found that childhood abuse altered glucocorticoid receptor (GR) expression (by increasing methylation of the promoter and decreasing mRNA expression) (70); as GR expression aids in dampening the body's response to stress, it is postulated that early life adversity permanently inhibited these patients' ability to process stress appropriately. Although much remains to be parsed out about the relative contributions of maternal care (or neglect) and the ensuing outcome on sex-typical behaviour, major inroads have been made in terms of understanding altered epigenetic processes as a result of maternal care in rodent models. It will be interesting to see how and if maternal care confers a protective effect against development of psychiatric symptoms. 


\section{Epigenetic mechanisms governing repression and demethylation/ involvement in conferring risk or resilience to mental health disorders}

Although some co-activators are known to be involved in the aetiology of genetic disorders, such as CBP deletion in Rubinstein-Taybi syndrome (71) and E6-AP activity loss in Angelman syndrome $(15,72)$, disruptions in a number of repressors/co-repressors have been identified in sex-skewed neurodevelopmental disease ontogeny (see below), making them a particularly interesting target for investigation. We review the various factors involved in gene repression and consider how sex differences in these proteins may contribute to sex differences in risk and resilience.

\section{DNA methylation by DNA methyltransferases (DNMTs)}

Gene repression begins by enzymatic transfer of a methyl group to the $5^{\prime}$ carbon of a cytosine base $(5 \mathrm{mC})$, usually in the context of $\mathrm{CpG}$ 'islands', or regions of DNA rich in cytosine and guanine base pairs. Though methylation can occur at $\mathrm{CpA}, \mathrm{CpT}$, or $\mathrm{CpC}$ sites, it is less common (i.e. $\mathrm{CpG}$ methylation makes up approximately $40 \%$ of all $\mathrm{CpN}$ methylation) and does not occur as efficiently $(73,74)$. Methylation is accomplished by DNMTs. These include DNMT1, which binds hemi-methylated CpGs and is thus primarily considered to be a maintenance enzyme (75); DNMT3a, which results in de novo $5 \mathrm{mC}$ synthesis and is expressed more robustly around birth; DNMT3b, also capable of de novo $5 \mathrm{mC}$ formation but with high expression after conception that declines over time; and, finally, DNMT3L, the function of which is unclear, although it has been shown to lack enzymatic activity (76-78).

\section{Sex differences in DNMT expression: implications for psychiatric disorders?}

-Previous work from our laboratory has shown that, at post-natal day (PN)1, female rats express more DNMT3a than males in the amygdala but not the hypothalamus or POA. Female expression levels were reduced towards male-typical levels by prior injection of oestradiol benzoate or dihydrotestosterone, and sex differences were no longer observed by PN10. Furthermore, no sex difference at either time point was observed for DNMT1 (79). Additional evidence substantiated our finding that there is no sex difference in DNMT1 expression, although enzymatic activity is altered (i.e. males had greater activity than females) (80). Because DNMT overexpression has been noted in psychiatric disorders (81, 82) and there are sex differences in expression and activity, this may be one potential mechanism by which males and females exhibit sex differences in risk and resilience to mental illness.

\section{Recruitment of methyl binding domain (MBD) proteins and co-repressors to ensure gene suppression}

Upon methylation, gene repression is accomplished at several levels: first, methylation can physically block binding of transcription factors, thus preventing the assembly of coactivators and the recruitment of RNA polymerase II. Furthermore, MBD proteins [e.g. methyl-CpG-binding protein 2 (MeCP2), Mbd1, Mbd2, Mbd3, Mbd4 and Kaiso] recognise $5 \mathrm{mC}$ and can recruit co-repressors such as NCoR and SMRT (83), ultimately resulting in the acquirement of histone deacetylase (HDAC) activity. HDACs remove the acetyl group 
masking positively-charged lysine residues in histones and allow for tight packing of DNA and histones into chromatin, providing another mechanism by which access to a transcriptional start site is blocked (84). It is important to note that MBD protein binding may not always predict gene repression; for example, MeCP2 can bind CREB and increase gene expression (85), complicating the straightforward mechanism discussed above. The conditions under which this occurs are relatively unknown but appear to be an exception and not the rule.

MeCP2 and pervasive developmental disorders (Rett syndrome and autism)$\mathrm{MeCP} 2$ is an X-linked gene that was identified in a mutational screen for Rett syndrome (86), a neurodevelopmental disease primarily affecting females because it is usually embryonic lethal for males. Rett syndrome, similar to autism, is considered as a pervasive developmental disorder marked by severely impaired speech and social interactions, repetitive motor movements and seizures $(86,87)$. Interestingly, Nagarajan et al. (88) found that aberrant $M E C P 2$ promoter hypermethylation was a common feature of male autistic brain in post-mortem patient tissue samples, demonstrating that proper dosing of MeCP2 may be important in a variety of autism-spectrum disorders. We have observed a sex difference in neonatal rat MeCP2 mRNA on PN1, where females express more in the amygdala and the hypothalamus (but not the POA), which is eliminated by PN10 (89).

A lower level of MeCP2 expression at birth may put males at increased risk of developing symptoms inherent to $\mathrm{MeCP} 2$-related disorders. To test this concept, small interfering (si)RNA targeted to MeCP2 was directly infused into the amygdala of neonatal male and female rats for 3 days starting on the day of birth, and animals were subsequently raised, undisturbed, to the juvenile period (90). MeCP2 siRNA-infused males engaged in less juvenile social play behaviour, although no alterations in female social play behaviour were observed. Although the mechanism by which this occurs remains to be fully established, neonatal MeCP2 siRNA treatment reduced male-typical expression of arginine vasopression (AVP), a peptide hormone critical for proper social recognition in males that is organised by steroid hormone exposure during developmentally sensitive windows of time $(91,92)$. These data support the idea that male juvenile social interactions can be disrupted by perturbations in MeCP2 levels during a critical time point of amygdala development, and that disruptions in AVP expression may be involved. It is not known why females appear to be more resilient to perturbations in $\mathrm{MeCP} 2$ expression within the amygdala, although this may be a result of their normally higher levels of MeCP2 expression or the presence of a compensatory MeCP2 allele on the X chromosome.

\section{NcoR: evidence for involvement in anxiolytic aspects of mental health}

disorders-NcoR, one of the first co-repressors to be discovered (93), is ubiquitously expressed in the brain (94), and exhibits a sex difference within the amygdala and medial basal hypothalamus in rats that can be reversed by treatment at birth with steroid hormones (95). Despite the known binding affinity of NCoR to important epigenetic regulators such as MeCP2 and Kaiso $(96,97)$ and its known disregulation and abnormal localisation in Huntington's disease (98), very little work has been directed at understanding what involvement it may have in the development of psychiatric symptoms. A relatively recent 
study from our laboratory demonstrated that, by infusing the neonatal rat amygdala with siRNA targeting NCoR, juvenile play behaviour was 'hypermasculinised' in males specifically, and anxiety was elevated in both sexes (95). It will be interesting to determine whether there are links between heightened anxiety and increased rough-and-tumble play behaviour in males. These data illustrate that reductions in an epigenetic factor early in development can have sex-specific consequences on juvenile social interactions. This further supports the idea that the epigenome is sexually differentiated and perturbations to epigenetic regulatory factors may yield different outcomes depending on biological sex.

\section{Histone modifications}

Both co-activators and co-repressors recruit histone-modifying enzymes or possess intrinsic modifying activity; importantly, there are sex differences in the acetylation and methylation of mouse histone H3 (99) and in the expression of murine histone demethylases $(100,101)$. Histone modifications play an important role in regulation of gene transcription and repression and thus may help guide sexual differentiation of the brain. For example, males have a larger volume and more cells within the principal nucleus of the bed nucleus of the stria terminalis compared to females, and treatment with the HDAC inhibitor valproic acid disrupts this sex difference (102). Sex differences in histone acetylation patterns are important not only for brain morphology, but also for regulating adult behaviour. Specifically, treating newborn males with trichostatin A, an HDAC inhibitor, or infusing them with antisense oligodeoxynucleotides targeting HDAC2 and HDAC4, partially disrupts some adult male sexual behaviour (103). Additionally, trichostatin A can facilitate pairbonding in adult female prairie voles (104). Taken together, these data indicate that histone modifications occurring early in postnatal development are important in shaping lasting sex differences in brain and behaviour, and that chromatin modifications remain plastic throughout the lifespan.

\section{Active DNA demethylation}

Gene repression vis-á-vis cytosine methylation was previously considered to be a permanent modification. In cases where DNA demethylation was observed, the process was assumed to be passive in the sense that methylation marks were lost through successive rounds of cell division by, for example, inhibition of DNMT1 (105). Because most nerones are held in a quiescent state, it became clear that this could not fully account for DNA demethylation in the brain, and an older body of literature demonstrating the widespread existence of 5hydroxymethylcytosine (5hmC) (106) was subsequently unearthed. We now know $5 \mathrm{hmC}$ to be both a transitional state towards active DNA demethylation and the product of ten eleven translocation (TET) protein family oxidation. TETs were originally described as tumor suppressors, because chromosomal translocation mutations resulted in acute myeloid leukaemia (107). It was later realised that TET family proteins shared homology with trypanosomal 2-oxoglutarate/Fe(II)-dependent oxygenases, leading to their discovery as the enzymes responsible for formation of $5 \mathrm{hmC}(108)$.

Importantly, $5 \mathrm{hmC}$ represents approximately $40 \%$ of all modified cytosines in the brain and is enriched relative to $5 \mathrm{mC}$ in some cell types, including Purkinje cells, where it represents $0.6 \%$ of all nucleotides $(109,110)$, suggesting a significant role for this moiety in 
neuroepigenetic signalling. As shown in Fig. 2, in lieu of further TET1 oxidation, 5hmC can be modified by the activation-induced deaminase/apolipoprotein B mRNA editing cytokine (AID/APOBEC3) family, which converts the amine functional group of cytosine to a carbonyl, effectively generating uracil and, specifically, 5-hydroxymethyluracil (111). This molecule can be recognised by enzymes responsible for base excision repair via generation of a T:G mismatch, and appears to require Mbd4 and thymine DNA glycosylase (112). Gadd45b (growth arrest and DNA-damage-inducible, beta) is required for neuronal activityinduced DNA demethylation, and is assumed to act by recruiting AID/APOBEC3 and/or thymine DNA glycosylase to specific promoters [namely, brain-derived neurotrophic factor (BDNF) and fibroblast growth factor] (113). Alternatively, $5 \mathrm{hmC}$ can be further oxidised by TET1 to form 5-formylcytosine and 5-carboxycytosine (Fig. 2). Although little is currently known about these molecules and what they interact with, it is feasible that they serve to assemble signalling complexes. Future studies directed at understanding whether these oxidative intermediates interact with transcription factors would be illuminating.

Involvement in psychosis-It has recently been found that both Gadd45b and TET1 are overexpressed in post-mortem tissue from patients diagnosed with major psychosis (encompassing both schizophrenia and bipolar disorder) $(114,115)$. Furthermore, APOBEC3 was down-regulated and $5 \mathrm{hmC}$ was seen to accumulate. To assess the effects of these alterations in gene expression, BDNF and Gad67 were examined. BDNF is an important neurotrophin implicated in depression (as part of the so called 'neurotrophin hypothesis of depression') (116), whereas Gad67 is the enzyme responsible for making GABA, an important neurotransmitter in the brain previously shown to be disrupted in patients with schizophrenia (117). In the case of both BDNF and Gad67, promoters were found to be hyper-hydroxymethylated, whereas mRNA levels declined, indicating that the presence of $5 \mathrm{hmC}$ alone does not predict increased gene expression.

Interestingly, there appears to be a dynamic interplay between TET1 hydroxylation and $\mathrm{MeCP} 2$ binding, suggesting that $\mathrm{MeCP} 2$ may protect certain promoter regions from being targeted for active DNA demethylation. In a MeCP2 knockout mouse model, $5 \mathrm{hmC}$ increases by approximately $20 \%$, whereas MeCP2 overexpression causes a $25 \%$ reduction in $5 \mathrm{hmC}(110)$. Because MeCP2 expression has been clearly implicated in pervasive developmental disorders such as autism and Rett syndrome (88), the ensuing mis-regulation of TET1 hydroxylation may be an important avenue for future exploration. Further adding to this complexity, recent data collected in our laboratory show that, in neonatal rats, a transient reduction in Gadd45b expression (via targeted siRNA delivery into the neonatal amygdala) decreases MeCP2 expression by approximately 30\% (Kigar SL \& Auger AP, unpublished data), suggesting there are several pathways by which aberrant MeCP2 expression can be accomplished. Future work should be directed at understanding whether Gadd45b and/or TET1 expression is altered in autism-spectrum disorders or Rett syndrome.

\section{Maintenance of DNA methylation by steroid hormones}

Emerging evidence suggests that, at least in the brain, DNA methylation must be maintained to ensure normal function $(118,119)$. It has been shown that cycling between a methylated or demethylated state can happen rapidly, in the order of minutes in vitro (120). Although it 
remains to be determined how fast this switching occurs in vivo, it was recently demonstrated that circulating testosterone levels are required for maintenance of AVP methylation patterns and expression within the bed nucleus of the stria terminalis in adult male rat brain. Cessation of testosterone signalling following castration resulted in less promoter methylation of AVP and increased AVP mRNA, whereas the opposite pattern was seen in ERa (118). These data indicate that the presence of steroid hormones maintains neuronal methylation status. It will be important to determine which methyltransferases or demethylases are responsible for this active switching in the brain.

Because hormones appear to maintain methylated or demethylated states in rodents, it will be important to understand whether the same holds true in humans. Ageing is a natural phenomenon that results in a decrease or cessation of steroid hormone levels, as in menopause where there is a gradual discontinuation of oestrogen production from the ovaries. Notably, the symptoms of psychiatric disorders such as schizophrenia or neurodegenerative disorders such as Alzheimer's disease increase significantly after menopause, giving rise to the idea that oestrogen is 'neuroprotective' for women $(2,121)$. It is possible that a sustained decline in hormone levels results in changes to the epigenome that increase risk for some disorders. Future work examining the underlying molecular mechanisms will be of significant interest in treating these illnesses.

\section{Mental health disorders as epigenetic diseases}

We have outlined some of what is known about one of the first non-mother directed social behaviours (namely, juvenile social play) and addressed the involvement of a variety of epigenetic factors in its organisation. We have also presented a parsimonious model by which gene repression by $5 \mathrm{mC}$ can trigger recruitment of co-repressors or factors responsible for active DNA demethylation; however, it should be noted that $5 \mathrm{mC}$ does not de facto indicate repression (e.g. methylation occurring in the promoter of a co-repressor would be predicted to increase gene expression).

Despite the inherent complexities, establishing a more causative role for epigenetic molecules in human disease will be vital going forward because many mental health disorders are now being recognised as neurodevelopmental in origin, including schizophrenia $(2,122-124)$, autism $(1,125-127)$, anorexia nervosa $(5,128,129)$ and depression/anxiety $(130,131)$. In each of these cases, perinatal exposure to a chemical (e.g. testosterone, folic acid) or an environmental cue (e.g. nurturance, maternal depression) can create a lasting change in mental health risk or resilience. This is by nature epigenetic, as further supported by twin studies showing discordance in heritability of these disorders (5,132-134). Much remains to be determined about the advantages and disadvantages conferred by biological sex, and others have stressed the need to investigate basic sex differences in the brain, as well as include females in studies (135). There is, however, growing support for the culpability of hormones and the rearing environment as organisers of an epigenetic framework that determines risk and resilience to disease between the sexes. 


\section{References}

1. Baron-Cohen S, Knickermeyer RC, Belmonte MK. Sex differences in the brain: implications for explaining autism. Science. 2005; 310:819-823. [PubMed: 16272115]

2. Abel KM, Drake R, Goldstein JM. Sex differences in schizophrenia. Int Rev Psychiatry. 2010; 22:417-428. [PubMed: 21047156]

3. Dao DT, Mahon PB, Cai X, Kovacsics CE, Blackwell RA, Arad M, Shi J, Zandi PP, O’Donnell P, Knowles JA, Weissman MM, Coryell W, Scheftner WA, Lawson WB, Levinson DF, Thompson SM, Potash JB, Gould TD. Mood disorder susceptibility gene CACNA1C modifies mood-related behaviors in mice and interacts with sex to influence behavior in mice and diagnosis in humans. Biol Psychiatry. 2010; 68:801-810. [PubMed: 20723887]

4. Palanza P. Animal models of anxiety and depression: how are females different? Neurosci Biobehav Rev. 2001; 25:219-233. [PubMed: 11378178]

5. Bulik CM, Sullivan PF, Tozzi F, Furberg H, Lichtenstein P, Pedersen NL. Prevalence, heritability, and prospective risk factors for anorexia nervosa. Arch Gen Psychiatry. 2006; 63:305-312. [PubMed: 16520436]

6. American Psychiatric Association. Diagnostic and Statistical Manual of Mental Health Disorders. 4th edn. American Psychiatric Association; Washington, DC: 2000. text rev.

7. Aleman A, Kahn RS, Selten JP. Sex differences in the risk of schizophrenia; evidence from metaanalysis. Arch Gen Psychiatry. 2003; 60:565-571. [PubMed: 12796219]

8. Tang MX, Jacobs D, Stern Y, Marder K, Schofield P, Gurland B, Andrews H, Mayeux R. Effect of oestrogen during menopause on risk and age at onset of Alzheimer's disease. Lancet. 1996; 348:429-432. [PubMed: 8709781]

9. Bird A. Perceptions of epigenetics. Nature. 2007; 447:396-398. [PubMed: 17522671]

10. McCarthy MM, Arnold AP. Reframing sexual differentiation of the brain. Nat Neurosci. 2011; 14:677-683. [PubMed: 21613996]

11. Wallis MC, Waters PD, Graves JAM. Sex determination in mammals - before and after the evolution of SRY. Cell Mol Life Sci. 2008; 65:3182-3195. [PubMed: 18581056]

12. Reyes FI, Boroditsky RS, Winter JSD, Faiman C. Studies on human sexual development II. Fetal and maternal serum gonadotropin and sex steroid concentrations. J Clin Endocrinol Metab. 1974; 38:612-617. [PubMed: 4856555]

13. Whalen RE, Edwards DA. Hormonal determinants of development of masculine and feminine behavior in male and female rats. Anat Rec. 1967; 157:173-180. [PubMed: 6034297]

14. Baum MJ. Differentiation of coital behavior in mammals: a comparative analysis. Neurosci Biobehav Rev. 1979; 3:265-284. [PubMed: 120519]

15. Tetel MJ, Auger AP, Charlier TD. Who's in charge? Nuclear receptor co-activator and corepressor function in brain and behavior. Front Neuroendocrinol. 2009; 30:328-342. [PubMed: 19401208]

16. Auger AP, Jessen HM, Edelmann MN. Epigenetic organization of brain sex differences and juvenile social play behavior. Horm Behav. 2011; 59:358-363. [PubMed: 20619265]

17. LeDoux J. The amygdala. Curr Biol. 2007; 17:R868-R874. [PubMed: 17956742]

18. Phelps EA, LeDoux JE. Contributions of the amygdala to emotion processing: from animal models to human behavior. Neuron. 2005; 48:175-187. [PubMed: 16242399]

19. Laberge F, Mühlenbrock-Lenter S, Grunwald W, Roth G. Evolution of the amygdala: new insights from studies in amphibians. Brain Behav Evol. 2006; 67:177-187. [PubMed: 16432299]

20. Shaw P, Lawrence EJ, Radbourne C, Bramham J, Polkey CE, David AS. The impact of early and late damage to the human amygdala on 'theory of mind' reasoning. Brain. 2004; 127:1535-1548. [PubMed: 15155523]

21. Schumann CM, Bauman MD, Amaral DG. Abnormal structure or function of the amygdala is a common component of neurodevelopmental disorders. Neuropsychologia. 2011; 49:745-759. [PubMed: 20950634]

22. Amaral DG, Bauman MD, Schumann CM. The amygdala and autism: implication from non-human primate studies. Genes Brain Behav. 2003; 2:295-302. [PubMed: 14606694] 
23. Johansen JA, Jordan CL, Breedlove SM. Steroid hormone masculinization of neural structure in rats: a tale of two nuclei. Physiol Behav. 2004; 83:271-277. [PubMed: 15488544]

24. Auger AP, Olesen KM. Brain sex differences and the organisation of juvenile social play behavior. J Neuroendocrinol. 2009; 21:519-525. [PubMed: 19500222]

25. Goy RW, Deputte BL. The effects of diethylstilbertrol (DES) before birth on the development of masculine behavior in juvenile female rhesus monkeys. Horm Behav. 1996; 30:379-386.

[PubMed: 9047264]

26. Meaney MJ, Stewart J, Poulin P, McEwen BS. Sexual differentiation of social play in rat pups is mediated by the neonatal androgen-receptor system. Neuroendocrinology. 1983; 37:85-90. [PubMed: 6888663]

27. Meaney MJ, Stewart J. Neonatal androgens influence the social play of prepubescent rats. Horm Behav. 1981; 15:197-213. [PubMed: 7250910]

28. Pellis SM, Pellis VC, McKenna MM. Feminine dimension in the play fighting of rats (Rattus norvegicus) and its defeminization neonatally by androgens. J Comp Psychol. 1994; 108:68-73. [PubMed: 8174346]

29. Olesen KM, Jessen HM, Auger CJ, Auger AP. Dopaminergic activation of estrogen receptors in neonatal brain alters progestin receptor expression and juvenile social play behavior. Endocrinology. 2005; 146:3705-3712. [PubMed: 15919740]

30. Meaney MJ, McEwen BS. Testosterone implants into the amygdala during the neonatal period masculinize the social play of juvenile female rats. Brain Res. 1986; 398:324-328. [PubMed: 3801906]

31. Yokosuka M, Okamura H, Hayashi S. Postnatal development and sex differences in neurons containing estrogen receptor-a immunoreactivity in the preoptic brain, the diencephalon and the amygdala in the rat. J Comp Neurol. 1998; 389:81-93. [PubMed: 9390761]

32. Whiting B, Edwards CP. A cross-cultural analysis of sex differences in the behavior of children aged three through 11. J Soc Psychol. 1973; 91:171-188.

33. DiPietro JA. Rough and tumble play: a function of gender. Dev Psychol. 1981; 17:50-58.

34. Humphreys AP, Smith PK. Rough and tumble, friendship, and dominance in school children: evidence for continuity and change with age. Child Dev. 1987; 16:201-212.

35. Ward C, Bauer EB, Smuts BB. Partner preferences and asymmetries in social play among domestic dog, Canis lupus familiaris, littermates. Anim Behav. 2008; 76:1187-1199.

36. Caro TM. Sex differences in the termination of social play in cats. Anim Behav. 1981; 29:271279.

37. Olioff M, Stewart J. Sex differences in the play behavior of prepubescent rats. Physiol Behav. 1978; 20:113-115. [PubMed: 662934]

38. Panksepp JB, Siviy S, Normansell L. The psychobiology of play: theoretical and methodological perspectives. Neurosci Biobehav Rev. 1984; 8:465-492. [PubMed: 6392950]

39. Berridge KC, Kringelback ML. Affective neuroscience of pleasure: reward in humans and animals. Psychopharmacology. 2008; 199:457-480. [PubMed: 18311558]

40. Panksepp JB, Lahvis GP. Social reward among juvenile mice. Genes Brain Behav. 2007; 6:661671. [PubMed: 17212648]

41. Field EF, Whishaw IO, Pellis SM, Watson NV. Play fighting in androgen-insensitive tfm rats: evidence that androgen receptors are necessary for the development of adult playful attack and defense. Dev Psychobiol. 2006; 48:111-120. [PubMed: 16489596]

42. Amateau SK, Alt JJ, Stamps CL, McCarthy MM. Brain estradiol content in newborn rats: sex differences, regional heterogeneity and possible de novo synthesis by the female telencephalon. Endocrinology. 2004; 145:2906-2917. [PubMed: 14988386]

43. McAbee MD, Doncarlos LL. Estrogen, but not androgens, regulates androgen receptor messenger ribonucleic acid expression in the developing male rat forebrain. Endocrinology. 1999; 140:36743681. [PubMed: 10433226]

44. Ryan BC, Vandenbergh JG. Intrauterine position effects. Neurosci Biobehav Rev. 2002; 26:665678. [PubMed: 12479841] 
45. Whiting B, Edwards CA. A cross-cultural analysis of sex differences in the behavior of children aged three through eleven. J Soc Psychol. 1973; 91:177-188.

46. Dolhinow, P.; Bishop, N. Primate Patterns. Holt, Rinehart \& Winston; New York, NY: 1972. The development of motor skills and social relationships among primates through play.

47. White PC, Speiser PW. Congenital adrenal hyperplasia due to 21-hydroxylase deficiency. Endocr Rev. 2000; 21:245-291. [PubMed: 10857554]

48. Hines M, Kaugman FR. Androgen and the development of human sex-typical behavior: rough-andtumble play and sex of preferred playmates in children with congenital adrenal hyperplasia (CAH). Child Dev. 1994; 65:1042-1053. [PubMed: 7956464]

49. Berenbaum SA, Duck SC, Bryk K. Behavioral effects of prenatal versus postnatal andreogen excess in children with 21-hydroxylase-deficient congenital adrenal hyperplasia. J Clin Endocrinol Metab. 2000; 85:727-733. [PubMed: 10690883]

50. Hines M, Golombok S, Rust J, Johnston KJ, Golding J. Testosterone during pregnancy and gender role behavior of preschool children: a longitudinal, population study. Child Dev. 2002; 73:16781687. [PubMed: 12487486]

51. Knickmeyer RC, Wheelwright S, Taylor K, Raggatt P, Hackett G, Baron-Cohen S. Gender-typed play and amniotic testosterone. Dev Psychol. 2005; 41:517-528. [PubMed: 15910159]

52. Auyeung B, Baron-Cohen S, Ashwin E, Knickmeyer R, Taylor K, Hackett G, Hines M. Fetal testosterone predicts sexually differentiated childhood behavior in girls and in boys. Psychol Sci. 2009; 20:144-148. [PubMed: 19175758]

53. Weaver ICG, Cervoni N, Champagne FA, D’Alessio AC, Sharma S, Secki JR, Dymov S, Szyf M, Meaney MJ. Epigenetic programming by maternal behavior. Nat Neurosci. 2004; 7:847-854. [PubMed: 15220929]

54. Francis D, Diorio J, Liu D, Meaney MJ. Nongenomic transmission across generations of maternal behavior and stress responses in the rat. Science. 1999; 286:1155-1158. [PubMed: 10550053]

55. Liu D, Diorio J, Day JC, Francis DD, Meaney MJ. Maternal care, hippocampal synatptogenesis and cognitive development in rats. Nat Neurosci. 2000; 3:799-806. [PubMed: 10903573]

56. Champagne FA, Weaver ICG, Diorio J, Dymov S, Szyf M, Meaney MJ. Maternal care associated with the methylation of the estrogen receptor-a $1 \mathrm{~b}$ promoter and estrogen receptor a expression in the medial preoptic area of female offspring. Endocrinology. 2009; 147:2909-2915. [PubMed: 16513834]

57. Parent CI, Meaney MJ. The influence of natural variations in maternal care on play fighting in the rat. Dev Psychobiol. 2008; 50:767-776. [PubMed: 18846499]

58. Edelmann MN, Demers CH, Auger AP. Maternal touch moderates sex differences in juvenile social play behavior. PLoS ONE. 2013; 8:e57396. [PubMed: 23460849]

59. Homberg JR, Schiepers OJ, Schoffelmeer AN, Cuppen E, Vanderschuren LJ. Acute and constituitive increases in central serotonin levels reduce social play behavior in peri-adolescent rats. Psychopharmacology. 2007; 195:175-182. [PubMed: 17661017]

60. Higley JD, Linnoila M. Low central nervous system serotonergic activity is traitlike and correlates with impulsive behavior. A nonhuman primate model investigating genetic and environmental influences on neurotransmission. Ann NY Acad Sci. 1997; 836:39-56. [PubMed: 9616793]

61. Fairbanks LA, Melega WP, Jorgensen MJ, Kaplan JR, McGuire MT. Social impulsivity inversely associated with CSF 5-HIAA and fluoxetine exposure in vervet monkeys. Neuropsychopharmacology. 2001; 24:370, 378. [PubMed: 11182532]

62. Moore CL, Morelli GA. Mother rats interact differently with male and female offspring. J Comp Physiol Psychol. 1979; 93:677-684. [PubMed: 479402]

63. Moore CL. Maternal behavior of rats is affected by hormonal condition of pups. J Comp Physiol Psychol. 1982; 96:123-129. [PubMed: 7056895]

64. Edelmann MN, Auger AP. Epigenetic impact of simulated maternal grooming on estrogen receptor alpha within the developing amygdala. Brain Behav Immun. 2011; 25:1299-1304. [PubMed: 21352906]

65. Field T. Touch for socioemotional and physical well-being: a review. Dev Rev. 2010; 30:367-383.

66. Field T. Preschoolers in America are touched less and are more aggressive than preschoolers in France. Early Child Dev Care. 1999; 151:11-17. 
67. Harlow HF. The nature of love. Am Psychol. 1958; 13:673-685.

68. Harlow HF, Dodsworth RO, Harlow MK. Total social isolation in monkeys. Proc Natl Acad Sci USA. 1965; 54:90-97. [PubMed: 4955132]

69. Provençal N, Suderman MJ, Guillemin C, Massart R, Ruggiero A, Wang D, Bennett AJ, Pierre PJ, Friedman DP, Côté SM, Hallet M, Tremblay RE, Suomi SJ, Szyf M. The signature of maternal rearing in the methylome in rhesus macaque prefrontal cortex and T cells. J Neurosci. 2012; 32:15626-15642. [PubMed: 23115197]

70. McGowan PO, Sasaki A, D’alessio AC, Dymov S, Labonté B, Szyf M, Turecki G, Meaney MJ. Epigenetic regulation of the glucocorticoid receptor in human brain associates with childhood abuse. Nat Neurosci. 2009; 12:342-348. [PubMed: 19234457]

71. Petrij F, Giles RH, Dauwerse HG, Saris JJ, Hennekam RC, Masuno M, Tommerup N, van Ommen GJB, Goodman RH, Peters DJ, Breuning MH. Rubinstein-Taybi syndrome caused by mutations in the transcriptional co-activator CBP. Nature. 1995; 376:348-351. [PubMed: 7630403]

72. Nawaz Z, Lonard DM, Smith CL, Lev-Lehman E, Tsai SY, O’Malley BW. The Angelman syndrome-associated protein, E6-AP, is a coactivator for the nuclear hormone receptor superfamily. Mol Cell Biol. 1999; 19:1182-1189. [PubMed: 9891052]

73. Grafstrom RH, Yuan R, Hamilton DL. The characteristics of DNA methylation in an in vitro DNA synthesizing system from mouse fibroblasts. Nucleic Acids Res. 1985; 13:2827-2842. [PubMed: 4000965]

74. Ramsahoye BH, Biniszkiewicz D, Lyko F, Clark V, Bird AP, Jaenisch R. Non-CpG methylation is prevalent in embryonic stem cells and may be mediated by DNA methyltransferase 3a. Proc Natl Acad Sci USA. 2000; 97:5237-5247. [PubMed: 10805783]

75. Pradhan S, Bacolla A, Wells RD, Roberts RJ. Recombinant human DNA (cytosine-5) methyltransferase I Expression, purification and comparison of de novo maintenance methylation. J Biol Chem. 1999; 274:33002-33010. [PubMed: 10551868]

76. Yoder JA, Somen NS, Verdine GL, Bestor TH. DNA (cytosine-5) methyltransferases in mouse cells and tissues. Studies with a mechanism-based probe. J Mol Biol. 1997; 270:385-395. [PubMed: 9237905]

77. Okano M, Xie S, Li E. Cloning and characterization of a family of novel mammalian DNA (cytosine-5) methyltransferases. Nat Genet. 1998; 19:219-220. [PubMed: 9662389]

78. Feng J, Chang H, Li E, Fan G. Dynamic expression of de novo DNA methyltransferases Dnmt3a and Dnmt3b in the central nervous system. J Neurosci Res. 2005; 79:734-746. [PubMed: 15672446]

79. Kolodkin MH, Auger AP. Sex differences in the expression of DNA methyltransferase 3a in the rat amygdala during development. J Neuroendocrinol. 2011; 23:577-583. [PubMed: 21518035]

80. McCarthy MM, Auger AP, Bale TL, De Vries GJ, Dunn GA, Forger NG, Murray EK, Nugent BM, Schwarz JM, Wilson ME. The epigenetics of sex differences in the brain. J Neurosci. 2009; 29:12815-12823. [PubMed: 19828794]

81. Grayson DR, Guidotti A. The dynamics of DNA methylation in schizophrenia and related psychiatric disorders. Neuropsychopharmacology. 2013; 38:138-166. [PubMed: 22948975]

82. Zhubi A, Veldic M, Puri NV, Kadriu B, Caruncho H, Loza I, Sershen H, Lajtha A, Smith RC, Guidotti A, Davis JM, Costa E. An upregulation of DNA-methyltransferase 1 and 3a expressed in telencephalic GABAergic neurons of schizophrenia patients is also detected in peripheral blood lymphocytes. Schizophr Res. 2009; 111:115-122. [PubMed: 19386473]

83. Auger AP, Jessen HM. Corepressors, nuclear receptors, and epigenetic factors on DNA: a tail of repression. Psychoneuroendocrinology. 2009; 34S:S39-S47. [PubMed: 19545950]

84. Auger AP, Auger CJ. Epigenetic turn ons and turn offs: chromatin reorganization and brain differentiation. Endocrinology. 2011; 152:349-353. [PubMed: 21047950]

85. Chahrour M, Jung SY, Shaw C, Zhou X, Wong STC, Qin J, Zoghbi HY. MeCP2, a key contributor to neurological disease, activates and represses transcription. Science. 2008; 320:1224-1229. [PubMed: 18511691]

86. Amir RE, Van den Veyver IB, Wan M, Tran CQ, Francke T, Zoghbi HY. Rett syndrome is caused by mutations in X-linked MECP2, encoding methyl-CpG-binding protein 2. Nat Genet. 1999; 23:185-188. [PubMed: 10508514] 
87. Ramocki MB, Peters SU, Tavyev YT, Zhang F, Carvalho CMB, Schaaf CP, Richman R, Fang P, Glaze DG, Lupski JR, Zoghbi HY. Autism and other neuropsychiatric symtpoms are prevalent in individuals with MECP2 duplication syndrome. Ann Neurol. 2009; 66:771-782. [PubMed: 20035514]

88. Nagarajan RP, Hogart AR, Gwye Y, Martin MR, LaSalle JM. Reduced MeCP2 expression is frequent in autism frontal cortex and correlates with aberrant MECP2 promoter methylation. Epigenetics. 2006; 1:e1-e11. [PubMed: 17486179]

89. Kurian JR, Forbes-Lorman RM, Auger AP. Sex differences in Mecp2 expression during a critical period of rat brain development. Epigenetics. 2007; 2:173-178. [PubMed: 17965589]

90. Kurian JR, Bychowski ME, Forbes-Lorman RM, Auger CJ, Auger AP. Mecp2 organizes juvenile social behavior in a sex-specific manner. J Neurosci. 2008; 28:7137-7142. [PubMed: 18614683]

91. Forbes-Lorman RM, Rautio JJ, Kurian JR, Auger AP, Auger CJ. Neonatal MeCP2 is important for the organization of sex differences in vasopression expression. Epigenetics. 2012; 7:230-238. [PubMed: 22430799]

92. Han TM, De Vries GJ. Organizational effects of testosterone, estradiol, and dihydrotestosterone on vasopressin mRNA expression in the bed nucleus of the stria terminalis. J Neurobiol. 2003; 54:502-510. [PubMed: 12532400]

93. Hörlein AJ, Näär AM, Heinzel T, Torchia J, Gloss B, Kurokawa R, Ryan A, Kamei Y, Söderström M, Glass CK. Ligand-independent repression by the thyroid hormone receptor mediated by a nuclear receptor co-repressor. Nature. 1995; 377:397-404. [PubMed: 7566114]

94. van der Laan S, Lachize SB, Schouten TG, Vreugdenhil E, de Kloet ER, Meijer OC. Neuroanatomical distribution and colocalisation of nuclear receptor corepressor $(\mathrm{N}-\mathrm{CoR})$ and silencing mediator of retinoid and thyroid receptors (SMRT) in rat brain. Brain Res. 2005; 1059:113-121. [PubMed: 16212947]

95. Jessen H, Kolodkin M, Bychowski M, Auger CJ, Auger AP. The nuclear receptor corepressor has organizational effects within the developing amygdala on juvenile social play and anxiety-like behavior. Endocrinology. 2010; 151:1212-1220. [PubMed: 20051490]

96. Kokura K, Kaul SC, Wadhwa R, Nomura T, Khan MM, Shinagawa T, Yasukawa T, Colmenares $\mathrm{C}$, Ishii S. The Ski protein family is required for MeCP2-mediated transcriptional repression. J Biol Chem. 2001; 276:34115-34121. [PubMed: 11441023]

97. Yoon HG, Chan DW, Reynolds AB, Qin J, Wong H. N-CoR mediates DNA methylationdependent repression through a methyl CpG binding protein Kaiso. Mol Cell. 2003; 12:723-734. [PubMed: 14527417]

98. Boutell JM, Thomas P, Neal JW, Weston VJ, Duce J, Harper PS, Jones AL. Aberrant interactions of transcriptional repressor proteins with the Huntington's disease gene product, huntingtin. Hum Mol Genet. 1999; 8:1647-1655. [PubMed: 10441327]

99. Tsai HW, Grant PA, Rissman EF. Sex differences in the histone modifications in the neonatal mouse brain. Epigenetics. 2009; 4:47-53. [PubMed: 19029819]

100. Xu J, Deng X, Watkins R, Disteche CM. Sex-specific differences in expression of histone demethylases Utx and Uty in mouse brain and neurons. J Neurosci. 2008; 28:4521-4527. [PubMed: 18434530]

101. Xu J, Deng X, Disteche CM. Sex-specific expression of the X-linked histone demethylase gene Jarid1c in brain. PLoS ONE. 2008; 3:e2553. [PubMed: 18596936]

102. Murray EK, Hien A, de Vries GJ, Forger NG. Epigenetic control of sexual differentiation of the bed nucleus of the stria terminalis. Endocrinology. 2009; 150:4241-4247. [PubMed: 19497973]

103. Matsuda KI, Mori H, Nugent BM, Pfaff DW, McCarthy MM, Kawata M. Histone deacetylation during brain development is essential for permanent masculinization of sexual behavior. Endocrinology. 2011; 152:2760-2767. [PubMed: 21586557]

104. Wang H, Duclot F, Liu Y, Wang Z, Kabbaj M. Histone deacetylase inhibitors facilitate partner preference formation in female prairie voles. Nat Neurosci. 2013; 616:919-924. [PubMed: 23727821]

105. Wu SC, Zhand Y. Active DNA demethylation: many roads lead to Rome. Nat Rev Mol Cell Biol. 2010; 11:607-620. [PubMed: 20683471] 
106. Penn NW, Suwalski R, O'Riley C, Bojanowski K, Yura R. The presence of 5hydroxymethylcytosine in animal deoxyribonucleic acid. Biochem J. 1972; 126:781-790. [PubMed: 4538516]

107. Delhommeau F, Dupont S, Della Valle V, James C, Trannoy S, Mass e A, Kosmider O, Le Couedic JP, Robert F, Alberdi A, Lécluse Y, Plo I, Dreyfus FJ, Marzac C, Casadevall N, Lacombe C, Romana SP, Dessen P, Soulier J, Viguié F, Fontenay M, Vainchenker W, Bernard OA. Mutation in TET2 in myeloid cancers. N Engl J Med. 2009; 360:2289-2301. [PubMed: 19474426]

108. Tahiliani M, Koh KP, Shen Y, Pastor WA, Bandukwala H, Brudno Y, Agarwal S, Iyer LM, Liu DR, Aravind L, Rao A. Conversion of 5-methylcytosine to 5-hydroxymethylcytosine in mammalian DNA by MLL partner TET1. Science. 2009; 324:930-935. [PubMed: 19372391]

109. Szulwach KE, LI X, Li Y, Song C, Wu H, Dai Q, Irier H, Upadhyay AK, Gearing M, Levey AI, Vasanthakumar A, Godley LA, Chang Q, Cheng X, He C, Jin P. 5-hmC-mediated epigenetic dynamics during postnatal neurodevelopment aging. Nat Neurosci. 2011; 14:1607-1618. [PubMed: 22037496]

110. Kriaucionis S, Heintz N. The nuclear DNA base 5-hydroxymethylcytosine is present in Purkinje neurons and the brain. Science. 2009; 324:929-930. [PubMed: 19372393]

111. Conticello SG. The AID/APOBEC family of nucleic acid mutators. Genome Biol. 2008; 9:229. [PubMed: 18598372]

112. Guo JU, Su Y, Zhong C, Ming G, Song H. Emerging roles of TET proteins and 5hydroxymethylcytosines in active DNA demethylation and beyond. Cell Cycle. 2011; 10:26622668. [PubMed: 21811096]

113. Ma DK, Jang MH, Guo JU, Kitabatake Y, Chang MI, Pow-anpongkul N, Flavell RA, Lu B, Ming GI, Song H. Neuronal activity-induced Gadd45b promotes epigenetic DNA demethyltion and adult neurogenesis. Science. 2009; 323:1074-1077. [PubMed: 19119186]

114. Gavin DP, Sharma RP, Chase KA, Matrisciano F, Dong E, Guidotti A. Growth arrest and DNAdamage-inducible, beta (GADD45b)-mediated DNA demethylation in major psychosis. Neuropsychopharmacology. 2011; 37:531-542. [PubMed: 22048458]

115. Dong E, Gavin DP, Chen Y, Davis J. Upregulation of TET1 and downregulation of APOBEC3A and APOBEC3C in the parietal cortex of psychotic patients. Transl Psychiatry. 2012; 2:e159. [PubMed: 22948384]

116. Martinowich K, Manji H, Lu B. New insights into BDNF function in depression and anxiety. Nat Neurosci. 2007; 10:1089-1093. [PubMed: 17726474]

117. Lewis DA, Hashimoto T, Volk DW. Cortical inhibitory neurons and schizophrenia. Nat Rev Neurosci. 2005; 6:312-324. [PubMed: 15803162]

118. Auger CJ, Coss D, Auger AP, Forbes-Lorman RM. Epigenetic control of vasopressin expression is maintained by steroid hormones in the adult male rat brain. Proc Natl Acad Sci USA. 2011; 108:4242-4247. [PubMed: 21368111]

119. Dong E, Chen Y, Gavin DP, Grayson DR, Guidotti A. Valproate induces DNA demethylation in nuclear extracts from adult mouse brain. Epigenetics. 2010; 5:730-735. [PubMed: 20716949]

120. Métivier R, Gallais R, Tiffoche C, Le Péron C, Jurkowska RZ, Carmouche RP, Ibberson D, Barath P, Demay F, Reid G, Benes V, Jeltsch A, Gannon F, Salbert G. Cyclical DNA methylation of a transcriptionally active promoter. Nature. 2008; 452:45-50. [PubMed: 18322525]

121. Seeman MV. Psychopathology in women and men: focus on female hormones. Am J Psychiatry. 1997; 154:1641-1647. [PubMed: 9396940]

122. Børglum AD, Demontis D, Grove J, Pallesen J, Hollegaard MV, Pedersen CB, Hedemand A, Mattheisen M, GROUP investigators. Uitterlinden A, Nyegaard M, Ørntoft T, Wiuf C, Didriksen M, Nordentoft M, N€othen MM, Rietschel M, Ophoff RA, Cichon S, Yolken RH, Hougaard DM, Mortensen PB, Mors O. Genome-wide study of association and interaction with maternal cytomegalovirus infection suggests new schizophrenia loci. Mol Psychiatry. Jan 29.2013 :1-9. [PubMed: 23250327] 
123. Pedersen CB, Mortensen PB. Evidence of a dose-response relationship between urbanicity during upbringing and schizophrenia risk. Arch Gen Psychiatry. 2001; 58:1039-1046. [PubMed: 11695950]

124. Lewis DA, Levitt P. Schizophrenia as a disorder of neurodevelopment. Annu Rev Neurosci. 2002; 25:409-439. [PubMed: 12052915]

125. Knickmeyer R, Baron-Cohen S, Fane BA, Wheelwright S, Mathews GA, Conway GS, Brook CGD, Hines M. Androgens and autistic traits: a study of individuals with congenital adrenal hyperplasia. Horm Behav. 2006; 50:148-153. [PubMed: 16624315]

126. Volk HE, Lurmann F, Penfold B, Hertz-Picciotto I, McConnell R. Traffic-related air pollution, particulate matter, and autism. JAMA Psychiatry. 2013; 70:71-77. [PubMed: 23404082]

127. Surén P, Roth C, Brenahan M, Haugen M, Hornig M, Hirtz D, Lie KK, Lipkin WI, Magnus P, Reichborn-Kjennerud T, Schjølberg S, Davey SG, Øyen AS, Susser E, Stoltenberg C. Association between maternal use of folic acid supplements and the risk of autism spectrum disorders in children. JAMA. 2013; 309:570-577. [PubMed: 23403681]

128. Cnattingius S, Hultman CM, Dahl M, Sparén P. Very preterm birth, birth trauma, and the risk of anorexia nervosa among girls. Arch Gen Psychiatry. 1999; 56:634-638. [PubMed: 10401509]

129. Kaye WH, Wierenga CE, Bailer UF, Simmons AN, Bischoff-Grethe A. Nothing tastes as good as skinny feels: the neurobiology of anorexia nervosa. Trends Neurosci. 2013; 36:110-120. [PubMed: 23333342]

130. Hopkins J, Lavigne JV, Gouze KR, LeBailly SA, Bryant FB. Multi-domain models of risk factors for depression and anxiety symptoms in preschoolers: evidence for common and specific factors. J Abnorm Child Psychol. 2013; 41:705-722. [PubMed: 23504302]

131. Zahn-Waxler C, Shirtcliff EA, Marceau K. Disorders of childhood and adolescence: gender and psychopathology. Annu Rev Clin Psychol. 2008; 4:275-303. [PubMed: 18370618]

132. Rosenberg RE, Law JK, Yenokyan G, McGready J, Kaufmann WE, Law PA. Characteristics and concordance of autism spectrum disorders among 277 twin pairs. Arch Pediatr Adolesc Med. 2009; 163:907-914. [PubMed: 19805709]

133. Arseneault L, Milne BJ, Taylor A, Adams F, Delgado K, Caspi A, Moffitt TE. Being bullied as an environmentally mediated contributing factor to children's internalizing problems - a study of twins discordant for victimization. Arch Pediatr Adolesc Med. 2008; 162:145-150. [PubMed: 18250239]

134. Sullivan PF, Kendler KS, Neale MC. Schizophrenia as a complex trait - evidence from a metaanalysis of twin studies. Arch Gen Psychiatry. 2003; 60:1187-1192. [PubMed: 14662550]

135. McCarthy MM, Arnold AP, Ball GF, Blaustein JD, De Vries GJ. Sex differences in the brain: the not so inconvenient truth. J Neurosci. 2012; 32:2241-2247. [PubMed: 22396398] 
(A)

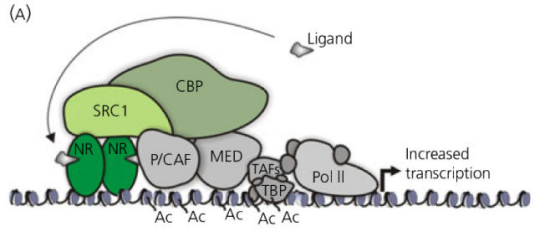

(B)

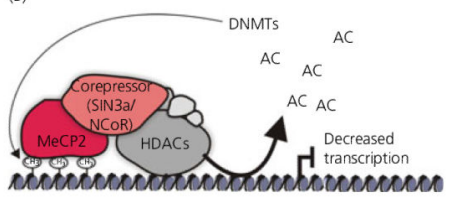

Figure 1.

(A) Ligand binding to nuclear receptors (NR) induces dimerisation and translocation to the nucleus, where assembly of co-activators [steroid receptor co-activator 1 (SRC-1), cAMPresponse element binding protein-binding protein (CBP) and p300/CBP-associated factor ( $\mathrm{P} /$ $\mathrm{CAF}$ )] acetylate and unwind DNA from histones and recruits transcription factors (including RNA polymerase II) to allow for gene transcription. (в) Cytosine methylation by DNA methyltransferases (DNMTs) recruits methyl-binding domain proteins (MBDs) such as $\mathrm{MeCP} 2$ and co-repressors (SIN3a/NCoR), which deacetylate histones and tightly wind DNA, thus preventing gene transcription. MED, mediator complex; TBP, TATA-binding protein; TAF, TBP-associated factors; AC, acetyl groups; NCoR, nuclear receptor corepressor; HDACs, histone deacetylases 


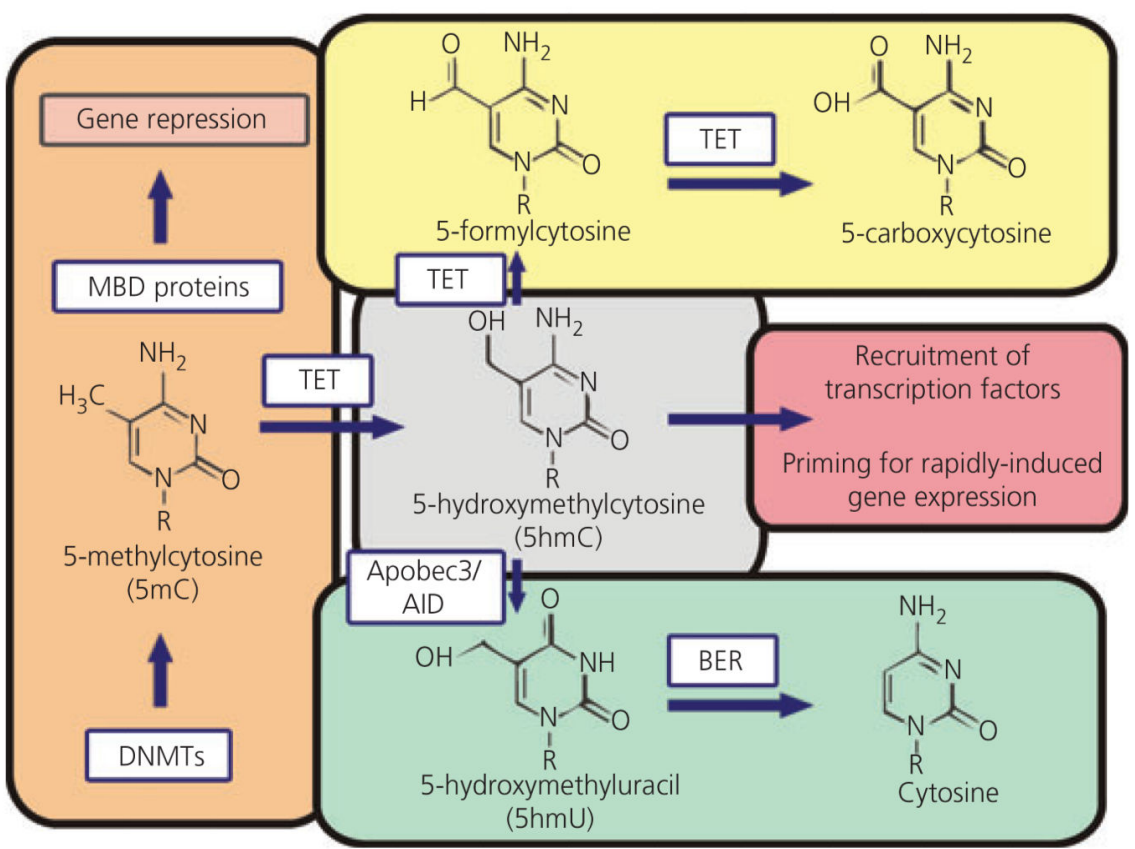

Figure 2.

DNA methyltransferases (DNMTs) add a methyl group to the $5^{\prime}$ carbon of cytosine. Methyl binding domain (MBD) proteins recognise this modification and recruit transcription factors to deacetylate histones and otherwise repress gene transcription. Alternatively, TET oxidation of 5-methylcytosine $(5 \mathrm{mC})$ leads to the formation of 5-hydroxymethylcytosine $(5 \mathrm{hmC})$, which can be further oxidised to 5-formylcytosine and 5-carboxycytosine (presumably these molecules can act as signalling scaffolds in their own right, although this remains to be seen). $5 \mathrm{hmC}$ can be deaminated by the activation-induced deaminase/ apolipoprotein B mRNA editing cytokine (AID/APOBEC3) family, leading to base excision repair in an active DNA demethylation pathway. Alternatively, $5 \mathrm{hmC}$ can serve as an intermediate signalling molecule, recruiting unique transcriptional complexes or otherwise 'priming' for gene expression. BER, base excision repair; TET, ten eleven translocation. 
Table 1

Data Compiled from the Diagnostic and Statistical Manual of Mental Disorders (6), Except Where Noted $(7,8)$.

\begin{tabular}{ll}
\hline Disorder $^{6}$ & Sex ratio (male : female) \\
\hline Attention deficit hyperactivity disorder & $80: 20$ \\
Autism & $80: 20$ \\
Schizophrenia $^{7}$ & $58: 42$ \\
Alzheimer's disease $^{8}$ & $30: 70$ \\
Anorexia nervosa & $7: 93$ \\
Anxiety disorder & $33: 67$ \\
Bulimia & $10: 90$ \\
Depression & $33: 67$ \\
\hline
\end{tabular}

Note that, although the determined sex difference in schizophrenia is small, the age of onset is earlier in males and is accompanied by more severe negative symptoms. 